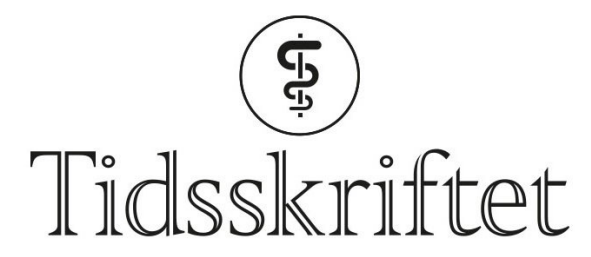

DEN NORSKE LEGEFORENING

\title{
Pasienter med hoftebrudd bør opereres innen 24 timer
}

FRA ANDRE TIDSSKRIFTER

PETTER MORTEN PETTERSEN

Tidsskriftet

Hoftebruddspasienter som opereres senere enn etter 24 timer, har høyere dødelighet enn dem som opereres tidligere. Dette viser en ny studie.

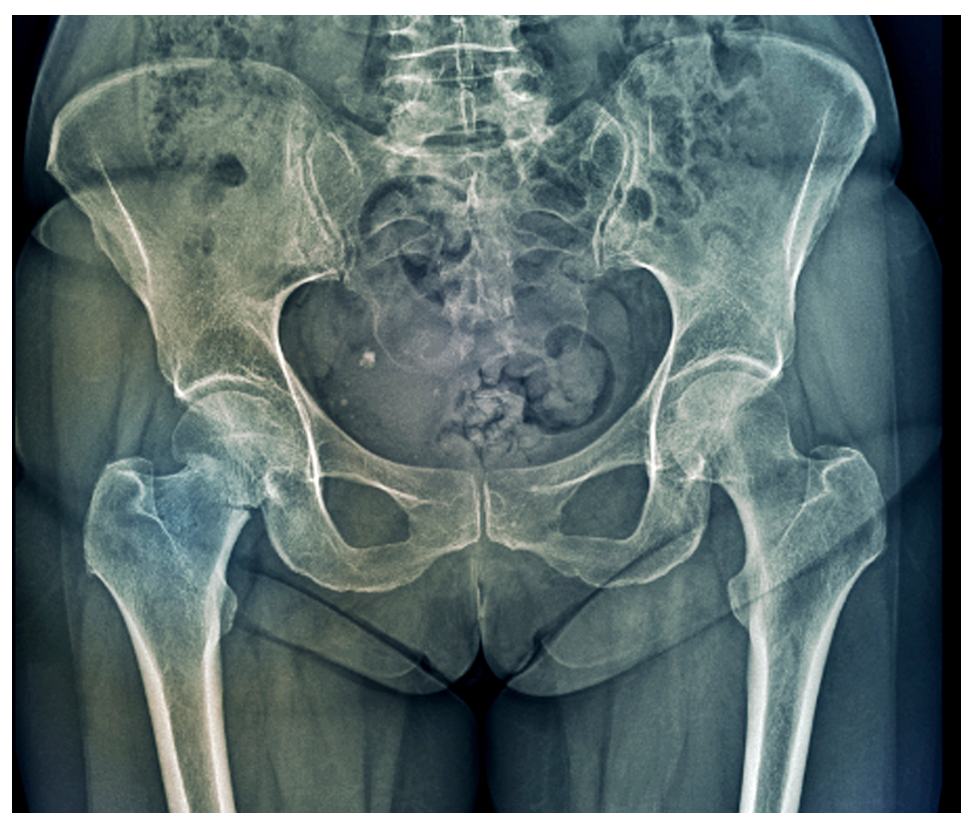

Høyresidig hoftebrudd. Illustrasjonsfoto: Science Photo Library / NTB scanpix

I en retrospektiv kohortstudie om behandling av hoftebrudd var målet å finne mulig sammenheng mellom preoperativ ventetid og 30-dagersdødelighet (1). Studien omfattet mer enn 42 ooo pasienter med hoftebrudd behandlet ved 72 sykehus i Canada i perioden 2009-14. Det var signifikant forskjell i risikojustert sannsynlighet for død innen 30 dager dersom operasjonen foregikk før eller etter 24 timer, henholdsvis $5,8 \%$ og 6,5\% (risikodifferanse 0,79\%, 95\% KI o,23-1,35)

- Denne studien er stor og viser tydelige resultater, men kommer strengt tatt ikke med noe vesentlig nytt, sier Frede Frihagen, som er overlege ved Hoftebruddsenheten ved Oslo universitetssykehus. - Alle retningslinjer og behandlingsanbefalinger om hoftebrudd tilsier at operasjonen skal finne sted så snart som mulig. Studien skilte ikke mellom ulike årsaker til lang ventetid, og ofte er nok årsaken begrenset operasjonskapasitet, sier Frihagen. 
- Selv om man har brukt avanserte statistiske metoder for å kontrollere for faktorer som gir $\emptyset \mathrm{kt}$ risiko, kan det tenkes at resultatet er påvirket av det forhold at noen pasienter trengte annen behandling før de kunne opereres. Slike pasienter har i utgangspunktet høyere dødsrisiko, sier han.

- I Norge er andelen hoftebruddspasienter som opereres innen 24 og 48 timer valgt som nasjonale kvalitetsindikatorer, og i 2016 var disse andelene henholdsvis $63 \%$ og $93 \%$. 30dagersdødeligheten var 8,4\%, opplyser Frihagen.

- Vi er langt fremme i forskningen om hoftebrudd, men ligger kanskje litt bak de flinkeste i å omsette kunnskap til bedre praksis, mener Frihagen, som påpeker at et bedre pasientforløp for gamle pasienter, ofte omtalt som ortogeriatri, er vist å bedre prognosen etter hoftebrudd. - De første norske behandlingsanbefalingene for hoftebrudd er like rundt hjørnet, sier han.

\section{LITTERATUR:}

1. Pincus D, Ravi B, Wasserstein D et al. Association Between Wait Time and 3o-Day Mortality in Adults Undergoing Hip Fracture Surgery. JAMA 2017; 318:1994 - 2003. [PubMed][CrossRef]

Publisert: 5. februar 2018. Tidsskr Nor Legeforen. DOI: 10.4045/tidsskr.17.1071

(C) Tidsskrift for Den norske legeforening 2020. Lastet ned fra tidsskriftet.no 